\title{
Die esoteriese aard van die New Age
}

\author{
L.F. Schulze \\ Departement Dogmatologiese en Ekklesiologiese Vakke \\ TSP/PUCHO \\ POTCHEFSTROOM
}

\begin{abstract}
Christian literature about the New Age seldom accenuotes its esoteric character. Yel, esotericism has been part and parcel of the new world view since its inception in theosophy. In dispensing occull knowledge, New Age adepts confrom Christianily wilh an allemative religious knowledge: experiential knowledge versus revelational knowledge. This escheric knowledge claims to unveil the hidden background of present world developments. Its cultivation needs different, antiecclesiastical fonts of worship and Scriptural intepretation. The inherent pontheism of New Age, however, doctrine implies an irrational dialectic, rendering it questionable. A Christian compromise with the New Age, a vintual mirror image of Christianity, is not possible.
\end{abstract}

\section{INIJEIDING}

Teen die koue rasionalisme, wat sedert die Verligting die Westerse kultuur gestempel het, het daar in ons eeu reaksie gekom. Die pendulum het na die ander kant beweeg en ons in die geestesklimaat van die irrasionalisme gebring (Van Gelder, 1991:413-416; Van Wersch, 1990:7-9). Laasgenoemde is reeds deur die Romantiek van die vorige eeu (met sy aksent op die subjektiewe, gevoelsmatige) voorberei (vgl. Van Wersch, 1990:9-10; Mathews, 1986:19,23,28-30) en het filosofies in die vitalisme en later in die eksistensialisme gestalte gekry.

Teologies gesien, het die swaai van die pendulum meegebring dat die deistiese godsbegrip van die rasionalisme vir 'n panteïstiese godsbegrip ingeruil is. Die afgeleë 'god' word nou gesien as die een wat naby die kosmos is - so naby dat hy in alles is en die kosmos deel van hom is. Hierdie panteïstiese visie, met sy gepaardgaande holisme, kom na vore in die uiteenlopende instansies, organisasies en persone wat die New Agelewensbeskouing voorstaan. By alle verskil in benadering, werkwyse en ideale is die panteisme die gemeenskaplike wat al hierdie organisasies saambind.

Fussel (1911:407) teken die godheid in onpersoonlike terme as "one eternal, immutable, all-pervading principle, the root of all manifestation" (vgl. Du Preez, 1991:144,150). Gevolglik kan hier nie van openbaring as wilsdaad van 'n persoonlike God sprake wees nie. Die mens is eerder op homself aangewys om deur bepaalde tegnieke van onthegting en meditasie die godheid in homself en in alle dinge te ontdek. Gepaard hiermee gaan die geweldige belewing dat 'ek' eén is met alle dinge. So word, 
kenteoreties gesien, openbaringskennis in die New Age-lewens- en wêreldbeskouing vir ervaringskennis ingeruil en leef die mens nie meer "van elke woord wat deur die mond van God uitgaan" (Matt. 4:4) nie, maar van dit wat hy van die godheid sélf kan ontdek en beleef.

Die ervaringskennis word langs mistieke weg ('n direkte godservaring) verkry en is esoteries van aard.

Die esoteriese aard (d.w.s. net aan ingewydes bekend - anon., 1973:41) van die New Age-leer maak dit, ten spyte van die pretensie om 'n samevatting van alle godsdienste te wees (Besant, 1922:301; Bailey, 1979:5-6), die teenpool van die Christendom. Hierdie wesenstrek word na my mening in die literatuur oor die New Age nie genoeg beklemtoon nie. In die werke van die propagandiste van die New Age word die esoteriese aard van hulle leer egter duidelik uitgestippel; daarom word in hierdie artikel hoofsaaklik op die esoteriese aard van die New Age gekonsentreer.

Eerstens word aangetoon dat die grondleggers van die New Age (die teosowe) en moderne verteenwoordigers daarvan (in besonder Creme) 'ingewydes' was (is), wat hulle kennis uit die 'hoër geesteswêreld' ontvang het. Tweedens word aangetoon dat daar deurgaans gepoog word om esoteriese kwekelinge te verkry. Derdens kom enkele aspekte van die inhoud van hierdie 'verborge' kennis, veral sover dit die loop van die geskiedenis raak, ter sprake. Vervolgens word die anti-kerklike aard van die geheime kennis belig. In 'n kritiese oorsig word die irrasionele dialektiek wat eie aan die panteîsme is, vanuit verskeie aspekte aangetoon en ten slotte word gestel dat die panteïstiese godsopvatting wat agter die esoteriese mistiek lè, die spieëlbeeld van die Christendom is. Daarom is 'n kompromie van die Christendom met die New Age onmoontlik (vgl. Van Wersch, 1990:12-13, wat ook II. Bcrkhof aanhaal).

Wanneer Christene besef dat hierdie kennis van God en van die kosmos nie deur die Drie-enige God bekend gemaak word nie mar deur die mens self uit 'n vreemde oord verkry word, word die onoorbrugbare kloof tussen die New Age en die Christendom duidelik.

New Age-literatuur is vrylik in ons land beskikbaar. Die tydskrif Odyssey, wat hom aandien as 'n tydskrif vir 'n beter lewenswyse, is die lyfblad van die nuwe denkrigting en word landwyd deur 'n groot boekwinkel versprei. Daarbenewens is werke van die ouere teosowe tot die mees moderne New Age-skrywers by die Aquarian Book Centre in Hillbrow te koop. Omdat Christene egter selde of ooit van hierdie leesstof besit, sal hier ruimskoots uit oorspronklike bronne aangehaal word.

\section{DIE INGEWYDES IN GEHEIME (OKKULTE) KENNIS}

Die bouers van die New Age-denke, naamlik die teosowe, het hulle kennis uit 'n hoër, geestelike sfeer ontvang. Dieselde geld vandag nog vir prominente propagandiste van 
die New Age. Hierdie toedrag van sake verbind die New Age met die spiritisme, hoewel dit nie impliseer dat alle voorstanders van die nuwe lewens- en wêreldbeskouing spiritiste is nie.

Die New Age-leer kom hoofsaaklik uit die Ooste en het in sy huidige vorm aanvanklik beslag gekry deur H.P. Blavatsky (1831-1891). In die uiteensetting van die leer het sy meestal outomaties geskryf. Cumbey (1983:44) meld die volgende:

Madame Blavatsky worked in "telepathic communication", serving as a "fulcrum" for the masters starting in 1867 and continuing until her death in $1891 .^{1}$

Dieselfde geld van Alice Bailey (1880-1949), die profetes van die New Age. In die woorde van Livesey (1986:31) het sy geskryf "as dictated from the spiritual realm ...". Die 'gees' onder wie se leiding sy geskryf het, het homself as "Die Tibetaan" aan haar voorgestel (Burger, 1987:3). Voor in Bailey se The Reappearance of the Christ is daar 'n verkorte weergawe van 'n verklaring van "Die Tibetaan".

Die nugter en selfs kritiese trant waarin die bekende New Age-skrywer David Spangler se Emergence: the Rebirth of the Sacred geskryf is, kan die indruk skep dat nugter rasionaliteit hier an die woord is. Tog is dit nie die geval nie. Bednarowski (1991:211) se: " ... it is something of a surprise to encounter his occasional references to 'John', a spiritual being with whom he communicates ... Spangler describes himself as John's colleague rather than as his agent or medium. He does not use the term 'channeler".

In Creme se boek, The Reappearance of the Christ and the Masters of Wisdom, is daar 'n dosyn boodskappe uit die ander wereld wat Creme telepaties ontvang het. Dit is saamgebundel as Selected Messages from Maitreya, the Christ (Creme, 1980:227-248).

Die hele New Age-leer is gevolglik in 'n sekere sin 'nie van hierdie wêreld nie'. Dit is verborge (okkulte) kennis van die dieper, geestelike werklikheid waarvan net ingewydes weet en dit dan verder bekend maak. Creme (1980:43) verduidelik:

1 Hierdie onistandighcid toon duidelik dat Blavatsky, soos sommige moderne New Agevoorstanders, uit dic staanspoor met die spiritisme verbind was. Trouens, haar verbintenis met die spiritisme is goed bekend - hoewel sy na die stigting van die Teosofievereniging haar van die spiritiste gedistansieer het (kyk Wisse, 1909:45-46). Spiritisme is die geloof dat oorledenes in bepaalde omstandighede met lewende mense op aarde deur middel van 'n medium, wat in 'n toestand van beswyming (trance) sy liggaam tydelik as werktuig van die gees van die afgestorwene beskikbaar slel, in verbinding kan tree (anon., 1977a:250). Soos Blavalsky in haar later jare, ontken Creme ook verband met die spritisme. Hy meld (1980:199) dat Alice Bailey botweg geweier het om 'n medium te wees "until she was assured by her own Master that this was nothing to do with mediumship, that it was the higher telepathy ..." Creme sé dat hy self ook sy boxdskappe, nic as 'n medium in loswyming nie, maar telepatics ontvang (19841:21). Ilier is hoogstens 'n verfynde vorm van spiritisme. Dic patroon bly diesclfde: 'n besonderc mens wat, hetsy in beswyming hetsy telepaties, as 'kanaal' vermeende boxdskappe vanuil die geesteswéreld na hierdie wêreld oordra. Vgl. ook Groothuis (1987:103): "a new Iype of spiritism" en DeParric \& Pride, 1990:17. 
Occult simply means hidden ... Occultism is the science of energy, but the hidden science of energy; the science of energy on the physical plane we call physics ...

The word, occult, in esotericism, has a particular meaning: it means not only hidden, but from the technical angle, that which is [sic| to do with the manipulation of energies. There are two main paths in esolericism - the occult way and the mystic way. The occultist is the mystic who is also the scientist, the scientist of energies, the practical mystic. Whereas the mystic is not necessarily the occultist.

Hierbo is gesê dat die New Age-leer in 'n sekere sin nie 'van hierdie wêreld is nie', omdat dit vanuit die geesteswèreld aan die mens meegedeel word. Aan die ander kant moet tegelyk gesê word dat die leer, in die woorde van Thiede (1991:65), vrug van 'n "natuurlike godsdienstigheid" is (vgl. ook Alexander, 1987:132). Die mens kan immers sélf deur bepaalde tegnieke na die hoër wêreld opklim en hierdie kennis bekom. Gevolglik bied die New Age godsdienstige kennis wat nie deur openbaring van bo af aan die mens meegedeel word nie maar wat van onder af deur die mens self verkry word. Dit hang op sy beurt daarmee saam dat die onpersoonlike, panteïstiese god van die New Age die heelal nie kon skep nie, en dat die kosmos as blote emanasie ' $\mathrm{n}$ manfestering van die godheid is. Openbaring as wilsdaad van die lewende, transendente God is gevolglik per definisie uitgesluit, en die mens het die taak om God in homself en in alle dinge te vind. Besant (1922:300) som dit kernagtig op: "No man is truly a theosophist who has no direct knowledge of God...".

\section{DIE KWEEK VAN INGEWYDES}

Die esoteriese aard van die New Age-leer veronderstel dat daar ook ingewydes moet wees wat hierdie kennis kan ontvang en verder kan deurgee. Daarom was die kweek van ingewydes reeds een van die doelstellings van die Teosofievereniging. Die doelstellings, wat in 1878 opgestel is, behels die volgende (Fussell, s.j.:4):

Het vormen van de kern cener Universecle Brocderschap in den ruimsten zin des woords.

De studic van oude en hedendaagsche godsdiensten, van wijsbegecrte en wetenschap, en het aantoonen van het grootc belang cener zoodanige studic.

Het onderzoek van de onverklaarde natuurwelten en van de psychische vermogens, die nog in den mensch sluimeren.

Alle lede moes met die eerste doelstelling instem, terwyl die nastrewe van die tweede en derde doelstellings opsioneel was. Dit verklaar waarom die meerderheid teosowe vurige voorstanders van ' $n$ wèreldbroederskap van alle mense was en dit in die alledaagse lewe probeer verwerklik hel, sonder om die dieper implikasies van hulle strewe te besef. Die ander, wat hulle toegelê het op die bereiking van die laaste twee doelstellings, is in esoteriese skole gevorm, "waar de geheimleer aan de ingewijden wordt onderwezen" (Kok, 1961:360). 
Die esoteriese skole het onder beheer van die Teosofievereniging gestaan. Vandag is sake anders. Omdat die New Age nie 'n vereniging, organisasie of beweging met ingeskrewe lede is nie, kan 'n mens streng gesproke nie van esoteriese skole van die New Age praat nie. Tog is hulle daar - gemeenskappe en opleidingsentrums wat onafhanklik van mekaar in dieselfde rigting werk en die studente leer om hulle sluimerende psigiese kragte te ontwikkel en te gebruik. Chandler (1990:68-79) bespreek 'n hele reeks groepe en instellings wat die New Age-gedagtes verbrei. Hulle wissel van tipies Oosterse kleur, soos byvoorbeeld die Hare Krishna-beweging, tot oënskynlik tipies Westerse wetenskaplike opleidingseminare wat poog om bewussynsverruiming en aktualisering van die menslike potensiaal by die kursusgangers teweeg te bring. 'n Voorbeeld van laasgenoemde is die Erhard Seminars Training (EST). Erhard se personal growth-seminare het van 1971 tot 1984 bykans 'n halfmiljoen mense gelok. Die Wall Street Journal beskryf hom pittig as "a guru of the Me generation" (aangehaal deur Chandler, 1990:72; vgl. ook Adeney, 1987:112; Hoyt, 1987:159,168-169).

Ten spyte van Blavatsky se breuk met die spiritisme en die ontkenning van mediumskap deur aanhangers van die New Age (kyk voetnoot 1), vorm kennis wat van 'hoër' geestelike entiteite verkry word die ruggraat van die $N$ ew $A g e$-leer.

Miller (1990:141) som die sukses wat met kwekelinge behaal is só op:

A new wave of spiritism is swecping America - the biggest since the initial outbreak of the phenomenon in the mid-nineteeth century ... The contemporary eruption of spiritism is calied the 'channeling' movement. Channeling could be called 'Spiritism New Age Style'.

Miller wys ook daarop dat $27 \%$ van die volwasse Amerikaanse bevolking in 1975 een of ander direkte kontak met afgestorwenes of ander geestelike wesens vermeld het. Tien jaar later het die persentasie tot 42 gestyg.

Die lewensbeskoulike uitgangspunte, onderliggende leer en psigologiese tegnieke van die veelvuldige opleidingsprogramme is 'n gebied vir verdere navorsing. Die werk van Hoyt op hierdie gebied verdien aanvulling. Ook die vraag of die kerke nie deur oorname en verchristeliking van sommige van hierdie programme reeds vreemde vuur op die altaar aangesteek het nie, verdien sorgvuldige oorweging.

\section{ASPEK'IE VAN DIE INIIOUD VAN DIE GEIIEIME KENNIS}

\subsection{Enkele historiese gegewens}

In 1889 het Blavatsky The Key to Theosophy geskryf. Daarin beweer sy dat daar 'n sikliese mededeling van kennis aan die mensdom tydens die laaste kwart van elke eeu plaasvind. Dit is pogings van die 'Meesters' om die geestelike vonruitgang van die mensdom te stimuleer. Die kennis wat meegedeel word, is van okkulte aard. Sy skryf (1908:194): 


\section{Die esoteriese aard van die New Age}

But 1 must Iell you that during the last quarter of every hundred years an altempt is made by those Masters, of whom I have spoken, to help on the spiritual progress of Humanity in a marked and definite way. Towards the close of each century you will find that an outpouring or upheaval of spirituality - or call it mysticism if you prefer - has taken place. Some one or morc persons have appeared in the world as their agents, and a greater or less [sic] amount of occult knowledge and teaching is given out.

Alice Bailey vertel in The Reappearance of the Christ (1949) dat daar in ons eeu mér gaan plaasvind as net die mededeling van kennis: in antwoord op die versugting en verwagting van ' $n$ mensdom in nood gaan die 'Meesters' en hulle leier, die 'Christus', in die afsienbare toekoms self verskyn om 'n nuwe menslike samelewing te vestig. Die algemene verwagting van Een wat gaan kom, is deur sowel die verkondiging van die kerk as die werk van esoteriese en okkulte groepe voorberei. Sy stel dit só (1979:19. 20):

Another unique factor which will distinguish His coming will be not only the general expectancy but also the fact that much is today known and taught about the Kingdom of God, or the Spiritual Hierarchy of the planct. Everywhere, in all countries, there are thousands who are interested in the fact of that Hierarchy, who believe in the Masters of the Wisdom, the disciples of the Chrisl, and who will not be surprised when this group of Sons of God, surrounding their greal Leader, the Christ, makes its appearance on Earth. The churches in all countrics have familiarised the public with the phrase "the Kingdom of God"; the esotericists and occultists everywhere have publicised the fact of the Hicrarchy during the past century, the spiritualists ${ }^{2}$ have laid the emphasis upon the aliveness of those who have passed over into the hidden world of being, and their Guides have also borne testimony to the existence of an inner, spiritual world. All this creates a unique preparedness which presents the Christ with unique opportunitics and unique problems.

Benjamin Creme, een van die invloedrykste New Age-skrywers, voer die verwagting van die Een wat kom tot breekpunt. Op 'n dag in 1982 het hy ' $n$ volbladadvertensie in koerante Jwarsoor die VSA laat plaas waarin aangekondig is (Martin, 1990:18):

The world has had enough ... of hunger, injustice, and war. There is an answer to our call for help, a world teacher for all humanity. THE CHRIST IS NOW HERE.

Hierdie sensasionele aankondiging - wat bloot die feit vermeld dat 'n Indiese ghoeroe hom in Londen gaan vestig het (Martin, 1990:18) - is reeds vyf jaar tevore deur Creme aan sy binnekring bekend gemaak. Creme vertel soos volg (1980:21):

During our Friday transmission session, the Master told me that Maitreya had been resting, acclimatising Himself, for three days, and that on that day, July 22nd [d.i. 1977], His Mission had bcgun. This information I could share with the group.

Hy vertel ook van die boodskap van die aankoms van Maitreya op aarde (Creme, 1980:20-21):

2 Lees spiritists. Spiritisme (kyk voctnoot 1) en spiritualisme moct immers duidelik onderskei word. Laasgenoemde is ' $n$ filosofiese term wat dic tecnoorgestelde van matcrialisme aandui. Dit sicn op 'n wêreldbeskouing wat aan die gees en die gecstelike dinge (in tecnstelling met die stonlike, uitwendige) die enigste ware realiteit tocken (anon., 1977b:250-251). 
On July 7th 1977, Maitreya Himself informed us that His body of manifestation - the Mayavirupa - was totally complete, that He had "donned" it, and that His Body of Light (His Ascended Body) was now at rest in His mountain Centre in the Himalayas. On July 8th, we were told, the Descent had begun. On Tuesday, July $19 \mathrm{~h}$, my Master told me that Maitreya had now arrived in His "point of focus", a well known modern country.

Radikaal anders as wat Christus self gesê het, naamlik dat sy koms sal wees soos die weerlig wat "uit die ooste uitslaan en tot in die weste skyn" (Matt. 24:27), ontvang Creme (1980:20) die boodskap dat alles voorlopig in newels van geheimsinnigheid gehul sal wees:

Just before the end, I was suddenly overshadowed by Maitreya Himself, my heart melied, and I had the greatest difficulty in keeping my voice steady. The following words were put into my mind:

"When the Christ returns, He will not at first reveal His Presence, nor will the Masters Who
precede Him; but gradually, steps will be taken which will reveal to men that there lives among
them now a man of outstanding, extraordinary, potency, capacity for love and service, and with a
breadth of view, far beyond the ordinary. Men and women, all over the world, will find
themselves drawn into the awareness of the point in the modern world wherein this man will
live; and from that centre of force will flow the True Spirit of the Christ, which will gradually
reveal to men that He is with us. Those who can respond to His Presence and His Teaching will
find themselves somewhat reflecting this love, this polency, this breadth of vision, and will go
into the world and spread abroad the fact that the Christ is in the world, and that men should
look to that country from which a certain Teaching is emanating. This will take place in a very,
relatively, short period of time, and will lead to the conclusive evidence that the Christ is in our
midst.

From that time onwards, the changes which will take place in the world will proceed with a speed unprecedented in the whole history of the planet. The next iwenty-five years will show such changes, changes so radical, so fundamental, that the world will be entirely changed for the belter."

\subsection{Creme se interpretasie van die geskiedenis}

Creme interpreteer die geskiedenis utopisties as 'n evolusionère proses wat uitloop op universele liefde en broederskap (1980:202). Hierdie siening van die geskiedenis hang saam met bepaalde astrologiese spekulasies oor die aard en effek van die tydperk van die Waterdraer wat ons nou binnegaan (vgl. byvoorbeeld Bailey, 1979:79-88;126-127). Die interessante aspek van Creme se vertolking van die geskiedenis is dat hy die drie historiese aspekte wat in die vorige punt uiteengesit is, as fases van dieselfde proses van kennismededeling ten nouste met mekaar verbind. Sedert die stigting van die Teosofievereniging in 1875, meen hy, word 'n onderwysing (teaching) aan die wêreld gegee met die oog op die nuwe samelewing wat die New Age van die Waterdraer sal meebring.

Die bekendmaking van die (okkulte) onderwysing het volgens Creme in drie fases geskied. Die voorbereidende fase het begin met die stigting van die Teosofievereniging en die uiteensetting van die leer in The Secret Doctrine van Madame Blavatsky. 
Die werke van Bailey, wat sy as "the amanuensis of the Master D.K." van 1919 tot 1949 geskryf het, verteenwoordig die oorgangsfase. Die volgende is die openbaringsfase, waartydens die massamedia in die proses van kennisverspreiding betrek sal word (Creme, 1980:199). Creme teken die derde fase soos volg (1980:199-200):

The next stage, the Revelatory Phase, we are told, will emerge, world-wide, through the medium of the radio, after 1975. That is because the Masters and the Christ will soon be in the world, and the revelation will take place through the medium of the radio (and Iclevision).

So verbind Creme teosofie en New Age ten nouste met mekaar as twee fases van dieseifde proses. Hierdie besonder innige verband word soms nie vermeld nie (vgl. byvoorbeeld Van der Walt, 1990:7-12) of nie voldoende beklemtoon nie (vgl. byvoorbeeld Chandler, 1990:47; Venter, 1990:61-63).

\section{ESOTERIESE KENNIS IS ANTT-KERKLIK}

\subsection{Die vergoeiliking van die afval}

Die ontkerkliking van die Weste word deur voorstanders van die New Age positief gewaardeer. Bailey (1979:17) sê byvoorbeeld die volgende:

Today, when He comes, He will find a world uniquely free from the grip and hold of ecclesiasticism; when He came before, Palestine was held in the vicious grasp of the Jewish religious leaders, and the Pharisees and the Sadducees were to the people of that land what the potentates of the church are to the people in the world today. But - there has been a usefut and wholesome swing away from Churchianity and from onthodax religion during the past century, and this will present a unique opportunity for the restoration of Irue religion and the prescntation of a simple return to the ways of spiritual living [my kursivcring].

Bailey se aanval is nie op die Christendom as sodanig gemik nie, want dit is volgens haar 'n uitdrukking - hoewel nie volkome konkreet nie - van die licfde van God wat immanent in sy skepping is. Haar aanval is bepaaldelik teen die kerk gemik, aan wie se adres ernstige verwyte gerig word (Bailey, 1979:140):

The church today is the tomb of the Christ and the stone of theology has been rolled to the door of the scpulchre.

Creme is ewe uitgesproke oor hierdie saak. Hy pak die skuld vir die afval op die kerke self, omdat hulle ' $n$ uitgediende beeld van Christus voorhou. Die uitgediende beeld (waarskynlik onbewus volgens Bultmann) kan onmoontlik meer deur die meerderheid van denkende mense aanvaar word. Hy redeneer soos volg (Creme, 1980:25):

People have been led to leave the Churches in large numbers because the Churches have presented a picture of the Christ impossible for the majority of thinking people today to accept as the One and Only Son of God, sacrificed by His Loving Father to save Humanity from the results of its sins; as a Blood Sacrifice straight out of the old and outworn Jewish Dispensation; as the unique revealer of God's nalure, once and forever, never to be enlarged and expanded as man himself grows in awareness and ability to receive other revelations of that Divine nature; and as waiting in some mythical and unattractive Heaven until the end of the world, when He will return in a cloud of glory to the sound of Angels' trumpets, and, descending from these clouds, inheril His Kingdom. 
Die Bybel en die ware Christelike leer word deur Bailey en Creme gnosties verstaan, dit wil sê as 'n geheime leer wat net deur ingewydes verstaan kan word, omdat hulle alleen by magte is om die verborge sin van die Skrif te begryp. Daarom is hulle kritiek nie teen die Christendom as sodanig gerig nie maar teen die kerk, wat die ware leer begrawe het. Hierdie gnosties georiënteerde kritiek is nie nuut nie. Mani (216-277), die stigter van die Manicheërs, het reeds die kerk van vervalsing en verduistering van die leer van Jesus verwyt (Quispel, 1959:559).

\section{2 'n Ander liturgie}

Die New Age-spiritualiteit vereis ook nuwe aanbiddingsvorme. Bailey (1979:151) het reeds ' $n$ halfeeu gelede gesê dat die bekende kerklike vorme van gebed en erediens (worship) deur die wetenskap van invokasie en evokasie ${ }^{3}$ vervang sal word. Ook Creme (1980:89) beweer: "... the practice of invocation will take the place of prayer and worship as we use it today". Hy (Creme, 1980:89) gaan dan voort om die kern van die nuwe godsdiens te teken:

The very heart and core of the new world religion will be the esoteric process of Initiation. The first two Initiations will take place outwardly, openly, on the physical plane, in temples of the lime - as the most sacred ceremonies of the new religion ... Through it, mankind will gradually enter into the Hierarchy.

Ondertussen kan Christene voortgaan om Christus aan te roep, hoewel dit eintlik nie wys is nie. Ilulle kan bid "To whoever is the focus for you" (Creme, 1980:135). Maar, so vervolg Creme dadelik:

... Christ is not God. He is not coming as God. He is an Embodiment of an aspect of God, the Love aspect of God. He is the embodied soul of all creation. He embodies the energy which is the consciousness aspect of that Being we call God.

You can pray to Him. He would rather, I don't know, but I think He would rather you didn't pray to Him, but to the God within you, which is also within Him. He is simply a belter, or clearer manifestation of It than you and me.

The Great Invocation, wat in 1945 deur die 'Christus' vrygestel is, word aanbeveel as ' $n$ gebed vir alle mense. Voor in die bogenoemde werk van Bailey is dit, saam met 'n verduideliking van die skoonheid en eenvoud daarvan, afgedruk. Creme (1980:39-41) wy ook drie bladsye aan 'n verduideliking van hierdie soort gebed (kyk Schulze, 1989:56 vir die teks).

\subsection{Allegoriese Skrifuitleg}

Die invloedryke kerkvader Origenes (185-254) se verklaring van Psalm 150 bied verbasingwekkende leesstof. Al die musiekinstrumente waarmee die Here geloof moet

3 Hierdic twee terme word vanweē hulle okkulte belading met opset hier gebruik. Die gedagte is dal, as die 'Meesters' reg aanger(eep - of liewer - ingeroep word (invoke), sal dit by hulle 'n respons oproep (einke). 
word, word wegvertolk as simbole wat die geestesingesteldheid van die enkeling of die gemeente as geheel verbeeld. Origenes was die vader van die leer van die drievoudige Skrifsin: die letterlike, sedelike en geestelike. Hy was van huis uit Christelik opgevoed. Tog het hy filosofie by die neo-Platonis, Ammonius Saccas, bestudeer. Origenes se opvatting van die geestelike lewe en kontemplasie het die ontwikkeling van die mistiek diepgaande beïnvloed (Van Unnik, 1960:334-335). Sy interpretasie 4 van Psalm 150 toon duidelik dat hierdie gnosties geneigde kerkvader vir die letterlike sin van die Skrif nie veel omgegee het nie.

Origenes is hier bloot as vroeë voorbeeld aangehaal van 'n omstandigheid wat ook in moderne New Age-literatuur aangetref word: die verband tussen gnostiek en allegorisering. Immers, as daar agter die werklikheid - wat ten diepste skyn is - na die dieper en blywende geestelike werklikheid gesoek word, is dit logies dat daar ook agter die teks na 'n dieper betekenis gesoek sal word. Omdat alles ten slotte met alles saamhang as verskillende manifesterings van die goddelike geheel, is dit vanselfsprekend dat die interpretasiemoontlikhede van 'n Bybelteks meervoudig is.

'n Voorbeeld van meervoudige interpretasie vind ons in die geskrifte van 'n bepaalde Oosterse leer wat as tantra bekend is - 'n leer wat deur die meeste ghoeroes na die Weste oorgeplant is. Alexander (1987:147) tipeer die taal van die tantra-geskrifte as "the language of mutable meaning" en beskryf dit soos volg:

The language of the tantras is the language of the twilight zonc: $\wedge$ form of usage in which various meanings fow logether, intersect, and branch out in a hundred different implications.

In Yoga teken Eliade (1969:250-251, aangehaal deur Alexander, 1987:147-148) hierdie gebruik van taal as nóg 'n vorm van ontkenning van die (skyn)werklikheid:

The semantic polyvalence of words finally substitutes ambiguity for the usual system of reference inherent in every ordinary language. And this destruction of language contributes in its own way, too, toward "breaking" the profanc universe and replacing it by a universe of convertible and integrable plancs.

Hierby voeg Alexander (1987:148) die skerpsinnige opmerking: "It has the same effect on language that tantra in general has on reality: It first fragments it, then diffuses it, and finally dissolves it".

Die Bybel as godsdienstige literatuur word deur aanhangers van die New Age ook as "language of the twilight zone" hanteer. Die meersinnige opvatting van Bybelse

4 Die terme verolking en interpretasie word ook hicr opsctlik gebruik omdat Origencs se omgang met die Skrif gecn werklike uitleg of verklaring is nic. Kyk hicroor Stoker, 1935: 27. 33. Dieselfde geld van New Age-aanhangers se Skrifhantering (kyk dic slotparagraal van 3.1 hierbo). 
gegewens sny na twee kante toe: die (esoteriese) vergeesteliking van gewone mededelings en (waar dit hulle pas) die letterlike opvatting van figuurlike spreekwyses. Hier volg voorbeelde van albei vorms van hulle soort Bybelinterpretasie.

Bailey (1979:126) lig die sluier oor die agtergrond en ware betekenis van die vier evangelies as sy skryf:

Little as the orthodox Christian may care to admit it, the entire Gospel story in its four forms or presentations, contains little else except symbolic details about the Mysteries which are (as far as humanity is concerned) five in all. These Mysteries indicate, in reality, five important points in the spiritual history of an aspirant; they indicate also five important stages in the progress of human consciousness ... Four ages have just passed away, astronomically speaking: Gemini, Taurus, Aries, and Pisces. Today Aquarius, the fifth age, is coming into power.

Holmes se werkie bevat 'n hoofstuk "God is Lig" (Holmes, 1988:19-21). Hierin vorm 1 Johannes 1:5 die vertrekpunt. Om te sien wat Holmes met hierdie teks maak, moet dit eers kortliks in sy Skriftuurlike verband gestel word.

Dit is duidelik dat Johannes se lesers in die war gebring is - waarskynlik deur 'n vroeë vorm van Christclike gnostisisme wat ontken het dat die Seun van God in Jesus waarlik mens geword het (Du Toit, 1959:705; Coetzee, 1989:348). Hierteenoor stel Johannes reeds in die inleiding van sy brief dat die apostels se getuienis aangaande Jesus Christus, die Woord van die Lewe, absoluut betroubaar is. Hulle het Hom in die realiteit van sy menswording immers gesien, gehoor en selfs met die hande aangeraak (vs. 1-3). Teen hicrdic agtergrond stel Johannes dit wat die apostels van Jesus ontvang het, naamlik dat God lig is en geen duisternis in Hom is nie, en wat die konsekwensie hiervan vir die lewe van die gelowiges is (vs. 5-6):

Dit is nou dic boxdskap wat ons by Hom gehoor het en aan julle verkondig: God is lig, en daar is geen duisternis in Hom nic. As ons beweer dat ons aan Hom deel het, en ons lewe in die duisternis, lieg ons en handel ons nic volgens dic waarheid nie.

Dit is duidelik dat lig op die smettelose reinheid van God sien en duistenis op die mag van die sonde. Holmes (1988:19) neem egter op tipies gnosties-panteistiese wyse lig lellerlik op, verecnselwig dit met kennis (gnosis) en buig die stelling só om dat alles (die kosmos) lig is:

Die stelling dat God Lig is, is die letterlike WAARHEID. Deur die Lig, wat ook die Kennis genoem word, vind dic openbaring van die Lewe plaas.

Hlierdie aspek van die Dric-enige God is die basiese stof of energie van alles in die skepping. Alles wat gemanifesteer is, is lig in verskillende vibrasies of frekwensies.

\section{KRTIIESE SAMEVATTING}

\subsection{Die dialcktiek in die panteīsme}

Onder die oënskynlik ongelyksoortige opleidingsprogramme, organisasies en groeperings met al hulle eklektiese ornamentasie lê daar tog 'n gemeenskaplike lewens- 
beskouing - panteisme. Dit is, in die woorde van C.S. Lewis "the only really formidable opponent" van die Christendom (aangehaal deur Alexander, 1987:131). Miskien is dit meer korrek om te sé dat panteïsme die enigste aantreklike alternatief vir 'n postChristelike mensdom is. Die panteìsme vat immers alle dinge saam in ' $n$ indrukwekkende geheel wat hulle god noem. "You are God. I am God. This microphone is God. This table is God. All is God" (Creme, 1980:110).

Juis hierdie (gedeeltelike of totale) identifikasie van die godheid met sy teëpool - die sigbare werklikheid (vgl. Creme, 1980:111) met sy skynkarakter - bring 'n onhoudbare dialektiese spanning in die godsbegrip. Die Christendom weet ook uit die Woord van God dat daar dieptes van rykdom en wysheid en kennis van God is wat bo die mens se begripsvermoë uitgaan; dat die gedagtes van die Here onnaspeurlik is (Rom. 11:33-34). Hierdie dinge is boredelik. Die dialektiese tweespalt in die panteïstiese godsleer maak dit daarenteen onherroeplik teenredelik. Luister weer na Creme (1980:110-111), wat uit sy stelling wat aan die slot van die vorige paragraaf aangehaal is, die volgende konklusie trek:

And because all is God, there is no God. God is not someone that you can point to and say "That is God". God is everything that you have ever known or could ever know - and everything beyond your level of knowing (my kursivering).

Omdat teogonie (die wording van God) en kosmogonie (die wording van die wèreld) oorvleuel, verskyn die irrasionele dialektiek nie net in die godsleer nie maar ook in die kosmologie en antropologie - vir sover hierdie onderskeidings binne 'n panteistiese sisteem sinvol kan wees! Al die implikasies van die dialektiek kan nie binne die bestek van hierdie artikel uitgewerk word nie. Gevolglik word hier met enkele voorbeelde volstaan.

\subsection{Voorbeelde van die dialektiek}

\subsubsection{Gebed}

Creme beveel aan dat daar liewer nie tot die 'Christus' gebid moet word nie maar tot die 'god' wat in ons is en wat ook in Hom is. Die opvallende is dat die 'Christus', die Avatar (vgl. Bailey, 1979:5), die (vrywillige) inkarnasie van 'n aspek van God, deurgaans as 'n Persoon, as He angedui word. "But Christ is not God", sé Creme (1980:135). Daarom moet die mens nie tot Hom bid nie. God self is egter - en hieroor is teosowe en New Agers van allerlei skakering dit roerend eens - 'n onpersoonlike Sat, 'n Dit (Kok, 1961:360). Creme praat konsekwent van God as It. Tot hierdie Dit moet ons bid. Gebed is egter ' $n$ gesprek van persoon tot Persoon. Ek kan gevolglik nie tot 'n Dit bid nie. As ek dit wel sou doen, is daar ërens 'n skroef los. As ek byvoorbeeld met die staanlamp op my lessenaar (wat ook god is) begin kommunikeer, behoort dit duidelik te wees dat iets nie pluis is nie. 
Daar is 'n tweede anonalie. Gebed veronderstel 'n bewuste gesprek met God. Creme (1980:111) stel dit egter duidelik dat ons nie in 'n normale bewussynstoestand God kan ken nie:

God cannot be known from the level from which 1 am speaking now. It is impossible. God can, I believe, be sensed and apprehended as an experience, from moment to moment only, as That which IS when we go bcyond our thought and abide in that state of unthinking awareness of the totality, without sense of self. Then we can know God.

Gebed is gevolglik in 'n dubbele sin onmoontlik. Bailey en Creme is daarom konsekwent as hulle sê dat gebed in die toekomstige wêreldgodsdiens deur invokasie vervang sal word. Maar wie word dan ingeroep? Nie God nie, want Hy is reeds teenwoordig as die diepste self van die mens. Dit is die 'Christus' en sy hiërargie van 'Meesters' wat ingeroep word om die wêreld se probleme op te los (Bailey, 1979:22, 152-153) - nie God nie maar vergoddelikte mense!

\subsubsection{Die Goddelike, huipbehoewende mens!}

Omdat alles ' $n$ manifestasie van God is, is Dit ook die diepste kern van die mens. Dit gee aan die mens 'n ongekende outonomie. Tog het die Goddelike, outonome mens die hulp van die 'Meesters' met die 'Christus' as hulle hoof nodig. Burrows (1987:42) teken hierdie anomalie in treffende taal:

It is a striking irony that those who so loudly bruited the message of the divine within ended up seeking counsel from spirits from the outside. The conclusion is inescapable: They went inside and, like the rest of us, found themselves wanting. Divinity is a burden that humanity simply cannot bear.

\subsubsection{Die hulphchoewende, Goddelike 'Meesters'}

Die voorgaande irrasionele situasie van die mens het sy refleks in die magteloosheid van die Goddelike 'Meesters' om die mensdom te help, tensy hulle kragdadig deur die mense ingeroep word. Die 'Meesters' is mense wat die siklus van reïnkarnasies deurloop het en die hoogste trap, naamlik oplossing in die Goddelike $A l$, bereik het en nou vrywillig inkarneer om die mensdom in hulle evolusie te help. Aan hulle hoof staan die 'Christus'. Hy kan die mensdom egter nie help nie, tensy die mense Hom massaal inroep. Bailey (1979:22) stel dit só: "They will evoke Him if they can stand with massed intent, with hope and expectancy".

Die Goddelike mens, hoewel afhanklik van die Goddelike 'Meesters', is, so lyk dit, tog ten slotte die outonome mens wat sy eie vooruitgang bepaal. Om dit te bereik, is die okkulte New Age-propaganda noodsaaklik.

\section{SLOT: DIE NEW AGE AS SPIEēLBEELD VAN DIE CIRISTENDOM}

Dit is verbasingwekkend dat die Christelike Westerse beskawing, wat "die goeie woord van God gesmaak het en die kragte van die toekomstige wêreld, en afvallig geword 
het" (Hebr. 6:5-6) sy heil weer in die voor-Christelike heidense bygeloof gaan soek presies daardie dinge wat vir die volk van God uitdruklik verbied is (Deut. 18:9-14). Hierdie toedrag van sake moet waarskynlik verklaar word deur die hardnekkigheid waarmee die leuen van die slang in die paradys tot vandag toe geglo word, naamlik dat die mens nie sal sterwe nie maar soos God sal wees (Gen. 3:4-5). Dit is die boodskap wat vandag nog deur okkulte, spiritistiese kanale opgevang word. Burrows (1987:44) stel dit soos volg (vgl. ook DeParrie \& Pride, 1990:18):

Whatever otber information may be dispensed, the affirmation of humanity's deity and the denial of death are messages universally delivered by envoys from the spirit world.

Die Christendom leef by die openbaring, die wilsdaad van die persoonlike, lewende God, waardeur Hy die misterie wat "van alle eeue af verborge was in God wat alles geskape het deur Jesus Christus" nou "vir almal aan die lig" gebring het (Ef. 3:9), naamlik "dat die heidene mede-erfgename is" (Ef. 3:6) van die heil wat Christus bewerk het. Dit is vir almal openlik aan die lig gebring (kyk ook DeParrie \& Pride, $1990 ; 20$ ) en het niks te doen met die 'misterie' van die astrologiese stand van die son in bepaalde sterrebeelde, wat net aan ingewydes bekend is nie (vgl. Bailey, 1979:126).

Die okkulte $\mathrm{New}$ Age-leer is dus geen sintese van alle godsdienste nie maar die aartsvyand van die Christendom. Alexander (1987:148-149) teken dit treffend in sy artikel oor die tantra, 'n belangrike bestanddeel van die New Age-leer wat deur Oosterse ghoeroes in die Weste ingevoer is:

Christianity and tantra face each other as virtual mitror images. Each system exalts what the other devalues and affirms what the other denics...

In tanira, perfection is the undisturbed self-awareness of the One, but this perfect bliss is spoiled by its descent into duality, manifestation, and illusion. In tantra, god goes wrong, while humanity and the universe suffer the consequences on his behalf, in the misery and alienation of existence. God has his illa $^{5}$, but we get the karma. ${ }^{6}$

In Christianity, God creates a perfect world He declares superbly good, but this excellent handiwork is spoiled by the descent of its stewards into sin and discbedience. In Christianity, humanity and the universe go wrong, while God suffers the consequences on our behalf in the agony and alienation of the crucifixion. Though we were yet sinners, Christ died for us".

It is a roundabout route to pinning the fall on God.

5 Lila is die (onwerklike) kosmiese 'spel'. Ferguson (1983:420) beskryf dit so: "God is the consciousness that manifests as lila, the play of the universe". Alexander (1987: 135) stel dit soos volg: "This world of apparent form and substance is really lila, the play of divine consciousness - the illusionary magic of duality."

6 Kama is volgens die Oosterse wysheid die "wet van oorsaak en gevolg" waarvolgens evolusie plaasvind. Dit hou in dat elke handeling, begeerte, gedagte van die mens onverbiddelik'n gevolg voortbring. Wat die mens dus in hierdie lewe doen, bepaal sy toestand in 'n volgende gereinkarneerde lewe (Kok, 1961:390, Fussell, 1911:408). 
Duideliker kan die New Age as spieëlbeeld van die Christendom nie geteken word nie.

\section{HIHL JOKGRAFIE}

ADENEY, F.S. 1987. Transpersonal Psychology: Psychology and Salvation Meet. (In Hoy, K. ed. The New Age Rage. Old Tappan, N.J. : Revell. p. 107-127.)

ALEXANDER, B. 1987. Tantra: Unraveling the Cosmos. (In Hoy, $K$ ed. The New Age Rage. Old Tappan, N.J. : Revell. p. 131-157.)

ANON. 1973. Esoteries. (In Ensiklopedic van die wèreld 4:41-42.)

ANON. 1977a. Spiritisme. (In Ensiklopedie van die wêreld 9:250.)

ANON. 1977b. Spiritualisme. (In Ensiklopedie van die wéreld 9:250-251.)

BAILEY, A.A. 1979. The Reappearance of the Christ. 9th edition. New York : Lucis Publishing.

BEDNAROWSKI, M.F. 1991. Literature of the New Age: A Revicw of Representative Sources. Religious Studies Review, 17(3):209-216. July.

BESANT, A. 1922. Theosophical Soxicly. (In Encyclopedia of Religion and Ethics 12:300-304.)

BLAVATSKY, H.P. 1908. The Key to Theosophy. 3rd rev. edition. London : The Theosophical Publishing Socicty.

BURGER, M.G. samest. 1987. Dic nuwe cra of dic tydperk van die Waterdraer. S.l. : Die Basuin.

BURROWS, RJ.L. 1987. A Vision for a New Humanity. (In Hoyt, K ed. The New Age Rage. Old Tappan, NJ. : Revcll. p. 33-51.)

CHANDLER, R. 19\%). Understanding the New Age. Repr. Milion Keynes : Word.

COETZEE, J.C. 1989a. Algemene inleiding to die drie briewe van Johannes. (In Van Zyl, A.H. hoofred. Verklarende Bybcl. Kaapslad : Lux verbi. NT p. 348.)

COETZEE, J.C. 1989b. Die ecrste brief van Johannes. (In Van Zyl, A.H. hoofred. Verklarende Bybel. Kaapstad : Lux verbi. NT p. 348-355.)

CREME, B. 1980. The Reappearance of the Christ and the Masters of Wisdom. London : Tara Press.

CUMBEY, C.E. 1983. The Hidden Dangers of the Rainbow. Rev. ed. Shreveport, Lovisiana : Huntinglon House.

DEPARRIE, P. \& PRIDE, M. 1990. Ancient Empires of the New Age. 3e Print. Westchester, Ill. : Crossway.

DU PREEZ, J. 1991. Lewens- en wércldbeskouing van die New Age-Beweging. Ned. Geref. Teologiese Tydskrif, 32(1):143-151. Januaric.

DU TOIT, J.F. 1959. Dic ecrste algemene brief van dic apostel Johannes. (In Die Bybel met verklarende antekeninge 3:705-717.)

FER(iUSON, M. 1983. The Aquarian Conspiracy. Repr. London : Granada.

FUSSEL, J.H. 1911. Theosophy. (In The New Schaff-Herzog Encyclopedia of Religious Knowledge 11:407-410.)

FUSSELL, J.H. s.j. De theosophische beweging. S.l. : s.i. (Kerk en secle. Seric iv(5).)

GROOTHUIS, D.R. 1987. Politics: Building an International Platlorm. (In Hoyt, K. ed. The New Age Rage. Old Tappan, N.J. : Revell. p. 91-106.)

HOLMES, A. 1988. Vanweê die tyd. Hogsback : Holmes.

HOYT, K.C. 1987. Personal Growth: Finding or Losing the Self. (In Hoy, K ed. The New Age Rage. Old Tappan, N.J. : Revell. p. 158-184.)

KOK, A.B.W.M. 1961. Theosophic. (In Christelijke Encyclopedic 6:359-360.)

LIVESEY, R. 1986. Understanding the New Age. Chichester : New Wine.

MARTIN, W. 1990. Die nuwe cra kultus. Afr. vert. deur P. Grobbelaar. Kaapstad : Struik.

MATHEWS, P.T. 1986. Aurier's Symbolist Art Criticism and Theory. Ann Arbor, Mich. : UMI Rescarch Press.

MILLER, E. 19\%0. A Crash Course on the New Age Movement. Grand Rapids, Mich. : Baker.

OUISPEL, G. 1959. Manicheisme. (In Christelijke Encyclopedie 4:558-560.)

SCHULZE, L.F. 1989. New Age: herlewing van die 'old age'. In die Skrifig, 23(4):48- 59. Descmber. 
STOKER, H.G. 1935. Uitlegging of interpretasic. Koers, 2(5):27-33. April.

THIEDE, W. 1991. Religiosität und Hoffnung im Kontext von New Age. Kenugma und Dogma, 37(1):63. 93. Jan.

VAN DER WALT, B.J. 1990. Die "New Age"-Beweging: 'n onskuldige eksentrisiteil, nuwe hoop, demoniese sameswering of duidelike uitdaging vir die Christen? (In Van der Walt, BJ., Fowler, S., \& Venter, J.J. Die "New Age"-Beweging. Potchefstroom : IRS. p. 1-32.)

VAN GELDER, C. 1991. Postmodernism as an Emerging Worldview. Calvin Theological Journal, 26(2):412-417. Nov.

VAN WERSCH, S. 1990. De gnostisch-occulte vloedgolf. Kampen : Kok.

VAN UNNIK, W.C. 1960. Origenes. (In Christelijke Encyclopedie 5:334335.)

VENTER, J.J. 1990. 'n Filosofiese perspektief op die New Age-Beweging. (In Van der Walt, B.J., Fowler, S., \& Venter, JJ. Die "New Age"-Beweging. Potchefstroom : IRS. p. 51-79.)

WISSE, G. 1909. De moderne Theosophie. Kampen : Kok. 